\title{
Effect of Ammonia Concentration on the Nitrification Potential of Ammonia Oxidizing Bacterial Isolates from Fish Processing Waste Effluents
}

\section{A. Devivaraprasad Reddy ${ }^{1}$, G. Subrahmanyam ${ }^{3}$, M.M. Dechamma ${ }^{2}$, B.B. Nayak ${ }^{4}$, Iddya Karunasagar $^{5}$ and Indrani Karunasagar ${ }^{6^{*}}$}

${ }^{1}$ Krishi Vigyan Kendra, Dr. YSR Horticultural University, Venkataramannagudem, West Godavari District, Andhra Pradesh - 534 101, India

${ }^{2}$ Department of Fisheries Microbiology, College of Fisheries, Karnataka Veterinary, Animal and Fisheries Sciences University, Mangalore-575 002, India

${ }^{3}$ Central Muga Eri Research and Training Institute, Central Silk Board, Lahdogiarh-785700, Jorhat, Assam, India

${ }^{4}$ Fish Harvest and Post Harvest Division, Central Institute of Fisheries Education,

Mumbai, Maharastra, India

${ }^{5}$ Senior Fishery Industry Officer, FAO, Rome

${ }^{6}$ Department of Biomedical Science, Nitte University Center for Science Education and Research, UNESCO MIRCEN for Biotechnology, K.S. Hegde Medical Academy, Nitte University, Mangalore - 575 018, India

\section{*Corresponding author}

\section{A B S T R A C T}

\begin{tabular}{|c|}
\hline Keywords \\
\hline $\begin{array}{l}\text { Ammonia } \\
\text { oxidation, AOB } \\
\text { strains, Ammonia } \\
\text { concentrations, } \\
\text { amoA gene, qPCR. }\end{array}$ \\
\hline Article Info \\
\hline $\begin{array}{l}\text { Accepted: } \\
\text { 21 June } 2017 \\
\text { Available Online: } \\
\text { 10 July } 2017\end{array}$ \\
\hline
\end{tabular}

The present investigation was carried out to understand the effect of ammonia concentrations on the rate of ammonia-oxidizing activity of ammonia oxidizing bacteria (AOB) isolates. Maximum ammonium removal by all the isolates was found at $3 \mathrm{ppm}$ ammonium concentration. However, AOB-12 and Nitrosomonas europaea ATCC 19718 cultures were found to be efficient at low ammonium concentration ( $3 \mathrm{ppm}$ and $8 \mathrm{ppm}$ ), whereas AOB-21and AOB consortia (AOB-12+AOB-21) performed well at high ammonium concentrations $(25,50,100$ and $200 \mathrm{ppm})$. These results were corroborated with ammonia monooxyginase ( $a m o A)$ gene copy numbers estimated by quantitative real time PCR (q-PCR). The maximum amoA gene copy numbers were recorded in $N$. europaea ATCC 19718 at ammonia level of 50 ppm followed by AOB-12 at 25 ppm and the consortia having maximum copy numbers at $100 \mathrm{ppm}$. This study indicates the promise of using native AOB cultures to remove ammonia from the waste waters prior to release into the environment.

\section{Introduction}

Ammonia oxidation (AO) is the first and rare limiting first step in nitrification is one of the key global nitrogen cycle (French et al., 2012).Until recently, ammonia oxidizing bacteria (AOB) of the beta and gamma proteobacteria were considered as key organisms to oxidize the ammonia (Leininger et al., 2006; French et al., 2012). Chemolithotrophic ammonia oxidizing bacteria obtains all of its energy for growth 
from the oxidation of ammonia to nitrite (Ensign et al., 1993) via the intermediate hydroxylamine and fixing carbon from carbon dioxide via the Calvin cycle (Arp et al., 2002; French et al., 2012). Recently the abundance of $\mathrm{AOB}$ has been determined by quantifying $16 \mathrm{~S}$ rRNA or amoA gene copies using quantitative polymerase chain reaction (qPCR) (Leininger et al., 2006; Wells et al., 2009; Subrahmanyam et al., 2014a,b). This qPCR method is robust, sensitive, and real time quantitative tool, that provides an equally informative substitute to FISH (Since the minimum cells needed to observe $-10^{3}$ to $10^{4}$ cells/ml), though it may be restricted by the potency of DNA extraction and PCR biases (Martin-Laurent et al., 2001; Bellucci and Curtis, 2011).

Water is the elixir of life and is becoming increasingly scarce. Maintaining their quality for reuse is the need of the hour. Water consumption and discharge of high-strength wastewater from in fish-processing industries are ecological concern world-wide. Disposal of waste water from industries related to fish processing presents a major problem because of their objectionable odour, high protein and residual ammonia content (Sankpal and Naikwade, 2012). The importance of maintaining quality and complying with regulations regarding liquid effluents that are becoming more stringent cannot be over emphasized. The industry requires proper wastewater treatment prior to its release into the environment or for its re-use. The discharge of untreated effluents by industries contaminates the groundwater of the surrounding environments (Adebisi and Fayemiwo, 2011). Therefore, industrial wastewaters are treated partially before their discharge into sewers, or subjected to suitable treatment processes to make them safe (Sulieman et al., 2010). A regular monitoring of waste water for essential parameters of water quality is essential to understand environmental pollution and develop measures for mitigation. The industry is in dire need of efficient system of wastewater treatment, which covers the mechanisms and processes used to treat protein and ammonia rich waters prior to its release into the environment.

Nitrifying organisms play a significant role in treating waste water (Limpiyakorn et al., 2011; Reddy et al., 2014). Limited studies are available on the efficacy of the ammonia oxidizing bacteria isolated from the effluents. In this study, we have investigated the effect of different ammonia concentrations on the responses of $\mathrm{AOB}$ isolates, by studying the ammonia-oxidizing activity and also the expression of amoA gene copy numbers by using qPCR.

\section{Materials and Methods}

\section{Cultures}

In our previous study, two native $\mathrm{AOB}$ strains (AOB-12; AOB-21) were isolated from fish processing effluents. These strains are identified as Nitrosomonas nitrosa and N. marina of Betaproteobacteria, respectively by $16 \mathrm{~S}$ rRNA gene sequencing analysis (Reddy et al., 2015). Consortia culture was prepared by mixing of AOB-12 and AOB-21 culture in the ratio of $1: 1$. The ammonia removal potentials of these isolates were compared with that of standard AOB pure culture, N. europaea (ATCC 19718). Fresh water media (FWM) was prepared as per French et al., (2012) used for the enrichment and maintaining the cultures incubated in dark at $26 \pm 1^{\circ} \mathrm{C}$ and the ammonia levels were monitored on alternate days.

\section{Effect of ammonia levels on cultures}

To investigate the influence of ammonia on the ammonia removal efficiency of $\mathrm{AOB}$ 
cultures were checked by growing the cultures in $100 \mathrm{ml}$ of mineral salt medium (MSM) with varying $\mathrm{NH}_{4}{ }^{+}$concentration ranging from $3 \mathrm{ppm}$ to $200 \mathrm{ppm}$ and corresponding amount of HEPES buffer (in the ratio of 1:4) $\mathrm{pH} 7.5$ in $250 \mathrm{ml}$ Erlenmeyer flasks with cotton stoppers. All the cultures were inoculated with $10 \%$ (vol/vol) conditioned cells and incubated in dark at $26 \pm 1{ }^{\circ} \mathrm{C}$. Triplicate samples were taken for analysis of ammonia, nitrate, and nitrite estimation. Ammonia and nitrate were estimated using standard kits (Merck Spectroquant, Germany) as per the manufacturer's protocol and expressed as ppm. Nitrite was estimated as per the method described in Nitrification Network (http://nitrificationnetwork.org/Nerecipe.php). Initial inoculum was taken as a control to check the initial amoA gene copy number.

\section{DNA extraction and polymerase chain reaction $(\mathrm{PCR})$}

DNA was extracted from $50 \mathrm{ml}$ of each grown cultures by using the CTAB method with slight modifications (Ausubel et al., 1995). DNA was diluted 1 in 10 and PCR performed using one primer set (amoA 332F/amoA822R) targeting amoA gene of AOB (Rotthauwe et al., 1997). Approximately 10 to $20 \mathrm{ng}$ of genomic DNA was used for the reaction in thermal cycler (DNA Engine, BioRad, M.J. Research Inc., USA).

The PCR was performed in $30 \mu \mathrm{l}$ volumes containing $3.0 \mu \mathrm{l}$ of $10 \mathrm{x}$ PCR buffer $(100 \mathrm{mM}$ Tris-HCl ( $\mathrm{pH} 8.3$ ) (HiMedia, Mumbai, India), $20 \mathrm{mM} \mathrm{MgCl} 2,50 \mathrm{mM} \mathrm{KCl}, 0.1 \%$ BSA, 200 $\mu \mathrm{M}$ of each of the four dNTP, $0.2 \mu \mathrm{mol} / 1$ of each primer and $0.8 \mathrm{U}$ of taq polymerase (HiMedia, Mumbai, India). The PCR protocol comprised of 40 cycles of $60 \mathrm{sec}$ at $94^{\circ} \mathrm{C}, 60$ sec at $60^{\circ} \mathrm{C}$ and $60 \mathrm{sec}$ at $72^{\circ} \mathrm{C}$. The programme included an initial delay of $5 \mathrm{~min}$ at $94^{\circ} \mathrm{C}$ and final extension of $5 \mathrm{~min}$ at $72^{\circ} \mathrm{C}$ before and after 35 cycles, respectively. The PCR products were resolved in $2 \%$ agarose gels, stained with ethidium bromide $\left(5 \mathrm{ng} \mathrm{ml}^{-}\right.$ ${ }^{1}$ ) and analyzed using a gel documentation system (Gel Doc ${ }^{\mathrm{TM}} \mathrm{XR}^{+}$, BioRad, USA).

The amoA gene was cloned into expression

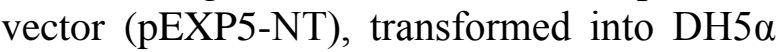
cells and cultured in LB following the standard protocol. Plasmid DNA was isolated using the alkaline lysis method (Sambrook, 1989) and used for the development of standard curve for absolute quantification of amoA gene copy number. The cloned circular plasmid was quantified using a Nano Drop ND-1000 spectrophotometer (USA). The copy numbers of the plasmids were calculated for standards by the following formula (Godornes et al., 2007). In order to calculate the number of grams/molecule also known as copy number requires the size of the plasmid that contains the gene of interest. A serial dilution of linearized plasmid DNA was used to generate a standard curve for q-PCR. From the standard curve, the copy number of the unknown samples can then be derived.

\section{Quantitative of amoA gene of $\mathrm{AOB}$ copy number by quantitative PCR}

The quantitative PCR (q-PCR) was performed with triplicate sets of extracted DNA using a Step One Plus ${ }^{\mathrm{TM}}$ Real-Time PCR System (Applied Biosystems, USA). The quantification of amoA genes was performed using the primer sets amoA 332F/amoA822R (Rotthauwe et al., 1997). The PCR mixture with a volume of $15 \mu \mathrm{l}$ contained $7.5 \mu \mathrm{l} 2 \mathrm{X}$ FastStart Universal SYBR Green Master Mix (Roche, Germany), $0.5 \mu$ l of each primer (0.4 $\mu \mathrm{M})$, and $1 \mu \mathrm{l}$ of each sample. The PCR conditions for the quantification of $a m o A$ gene copy numbers were $94^{\circ} \mathrm{C}$ for $3 \mathrm{~min}$, followed by 40 cycles of $30 \mathrm{~s}$ at $94{ }^{\circ} \mathrm{C}, 30 \mathrm{~s}$ at $55^{\circ} \mathrm{C}, 45 \mathrm{~s}$ at $72{ }^{\circ} \mathrm{C}$, with a data capture for 
each cycle at $80^{\circ} \mathrm{C}$ for $20 \mathrm{~s}$ and followed by melt curve. Data acquisition was performed by Step One software (v. 2.2.2) at the end of the each elongation step.

\section{Results and Discussion}

\section{Influence of $\mathrm{NH}_{4}^{+}$concentration on standard $N$. europaea}

Different ammonium concentrations were used to observe the growth and nitrification activity of the $N$. europaea. The $N$. europaea are having ability to reduce the ammonia in all the concentrations ranging from 3 to 200 $\mathrm{ppm}$. The percentage reduction in ammonia as well as amount of nitrification products (nitrite and nitrate) are shown in figure 1. The maximum activity in terms of ammonia removal (\%) is found in $3 \mathrm{ppm}$ of ammonium concentration followed by 8 ppm, 25 ppm, 50 ppm, 100 ppm and 200 ppm respectively.

Real time quantitative PCR (q-PCR) was done for the absolute copy number of amoA gene of $\mathrm{AOB}$ and is shown in figure 2. The initial inoculum added to the samples having an average $a m o A$ gene copies $1.97 \times 10^{9}$. The average maximum amoA gene copy numbers is found in $50 \mathrm{ppm}\left(3.80 \times 10^{9}\right)$ followed by $100 \mathrm{ppm}\left(3.10 \times 10^{9}\right), 200 \mathrm{ppm}\left(2.65 \times 10^{9}\right)$, respectively. The amoA gene copy numbers is comparatively less detected than the initial inoculum in $25 \mathrm{ppm}\left(1.92 \times 10^{9}\right), 8 \mathrm{ppm}$ $\left(2.05 \times 10^{8}\right)$ and 3 ppm $\left(3.965 \times 10^{7}\right)$ respectively.

\section{Influence of $\mathrm{NH}_{4}{ }^{+}$concentration on AOB- 12}

Different ammonium concentrations are used for the growth and nitrification activity of the AOB-12. It was found that AOB-12 had the ability to reduce ammonium in all the concentrations ranging from 3 to $200 \mathrm{ppm}$. The ammonia removal in ppm, percentage and products of nitrification (nitrite and nitrate) are shown in figure 3 . The maximum activity in terms of ammonia removal (\%) was found in $3 \mathrm{ppm}$ of ammonium concentration followed by $8 \mathrm{ppm}, 25 \mathrm{ppm}$, 100 ppm, 50 ppm and 200 ppm.

Real time q-PCR was done for the absolute copy number of amoA gene of $\mathrm{AOB}$ and is shown in figure 4 . The initial inoculum was added into the treatment samples having the average amoA gene copies are $7.3722 \times 10^{5}$. The maximum amoA gene copy numbers were found in $25 \mathrm{ppm}\left(4.14 \times 10^{6}\right)$, followed by $50 \mathrm{ppm}\left(3.82 \times 10^{6}\right), 100 \mathrm{ppm}(2.82 \times$ $\left.10^{6}\right), 200 \mathrm{ppm}\left(2.748 \times 10^{6}\right)$, and $8 \mathrm{ppm}$ $\left(1.3284 \times 10^{6}\right)$, respectively. However, the amoA gene copy number is comparatively less detected than the initial inoculum in case of concentration 3 ppm $\left(1.746 \times 10^{5}\right)$.

\section{Influence of $\mathrm{NH}_{4}{ }^{+}$concentration on AOB- 21 culture}

AOB-21 is having the ability to reduce the ammonium in all the concentrations ranging from 3 to $200 \mathrm{ppm}$. The ammonium removal and products of nitrification (nitrite and nitrate) are shown in figure 5. The maximum activity in terms of ammonium removal (\%) is found in $8 \mathrm{ppm}$ of ammonium concentration followed by 3 ppm, 25 ppm, 50 ppm, 100 ppm and $200 \mathrm{ppm}$. The nitrification (nitrite + nitrate) rate is observed maximum at 200 ppm, followed by 100 ppm, 50 ppm, 25 ppm, and $8 \mathrm{ppm}$.

q-PCR was done for the absolute copy number of amoA gene of AOB and is shown in figure 6 . The initial inoculum was added into the treatment samples having the amoA gene copies with an average of $6.487 \times 10^{6}$. The maximum amoA gene copy numbers was found in $8 \mathrm{ppm}\left(2.31 \times 10^{8}\right)$, followed by 25 ppm $\left(1.85 \times 10^{8}\right), 50 \mathrm{ppm}\left(7.65 \times 10^{7}\right), 100$ $\operatorname{ppm}\left(5.81 \times 10^{7}\right), 200 \operatorname{ppm}\left(4.84 \times 10^{7}\right)$ 
respectively. The AOB-21 is found to be very useful in aquaculture ponds, since it can withstand all the tested conditions and it can remove the ammonium effectively at different ammonium concentrations, compared to other isolates observed under this study.

Influence of $\mathrm{NH}_{4}^{+}$concentration on consortium of $\mathrm{AOB}-12$ and $\mathrm{AOB}-21$

In this experiment, the AOB12 and AOB21 are mixed and inoculated in to the flasks to see the ability of AOB consortia in group. The ammonia removal and products of nitrification (nitrite and nitrate) are shown in figure 7 . The maximum activity in terms of ammonia removal (\%) is found in $8 \mathrm{ppm}$ of ammonium concentration followed by 25 ppm, 50 ppm, 100 ppm and 200 ppm, respectively. The nitrification (nitrite + nitrate) rate was found to be maximum at 200 ppm, followed by 100 ppm, 50 ppm, 25 ppm, and $8 \mathrm{ppm}$ respectively.

Fig.1 Influence of $\mathrm{NH}_{4}{ }^{+}$concentrations (3 ppm to $200 \mathrm{ppm}$ ) on ammonia removal efficiency of $N$. europaea $($ mean $\pm \mathrm{SD} ; n=3)$
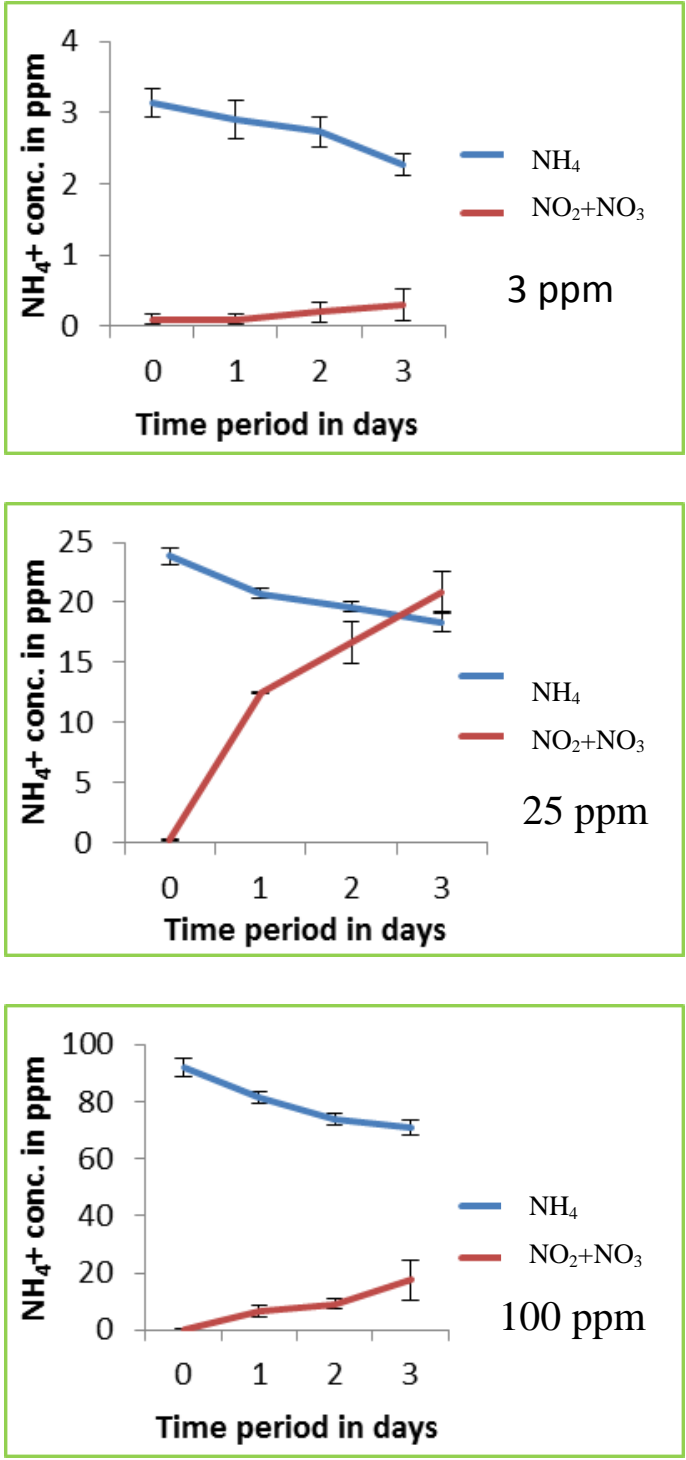
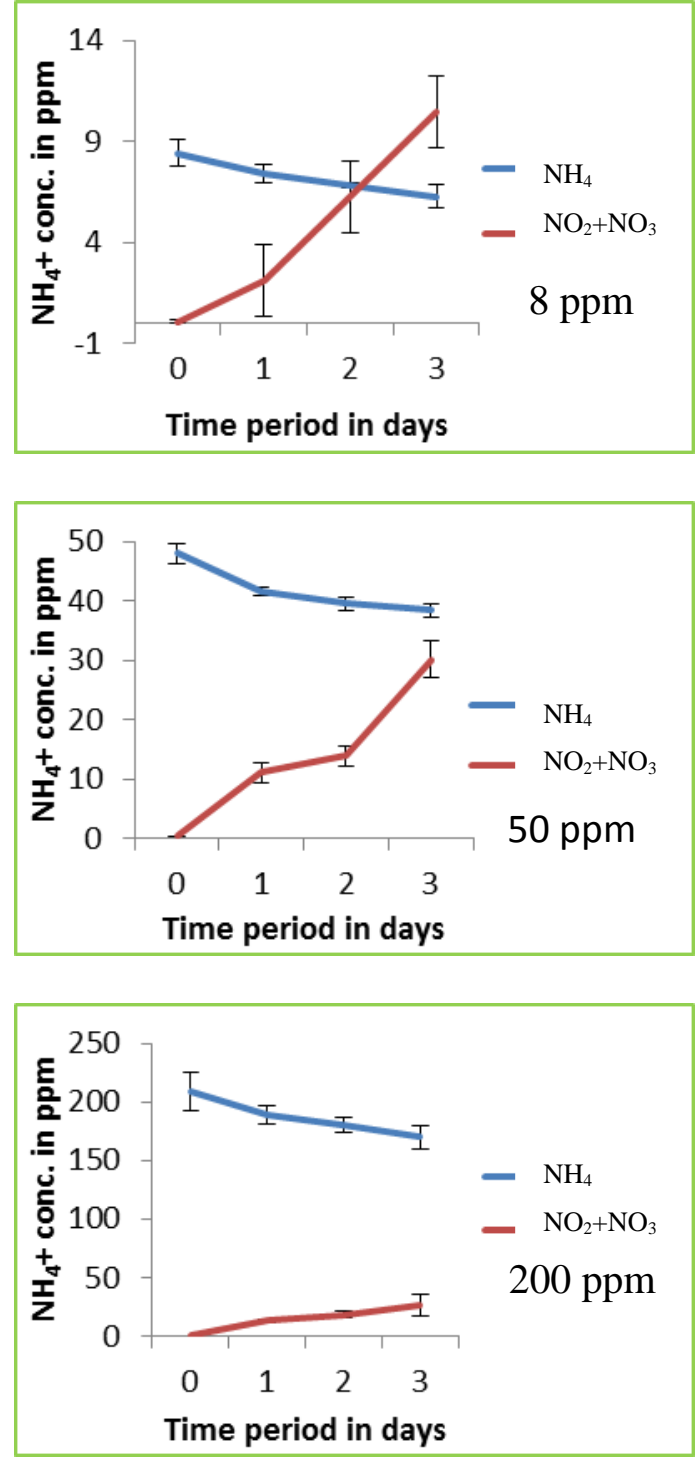
Fig.2 Influence of $\mathrm{NH}_{4}{ }^{+}$concentrations (3 ppm to $200 \mathrm{ppm}$ ) on amoA gene copy number of $N$. europaea as determined by qPCR

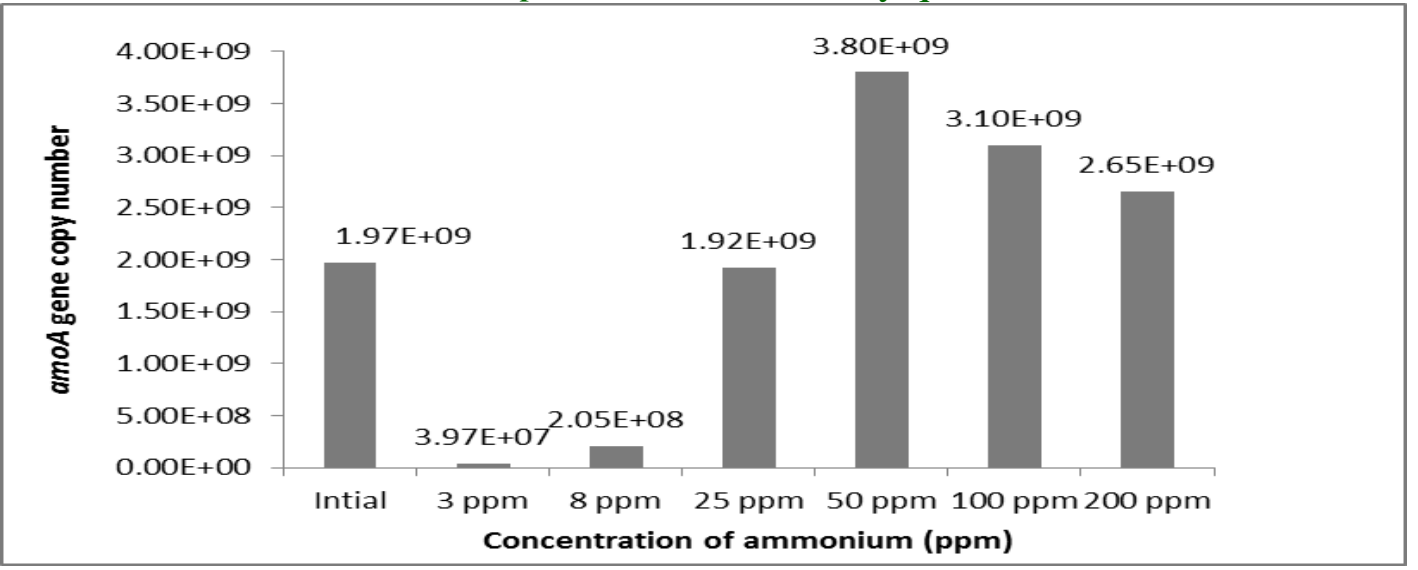

Fig.3 Influence of $\mathrm{NH}_{4}{ }^{+}$concentrations (3 ppm to $200 \mathrm{ppm}$ ) on ammonium removal efficiency of AOB-12 (mean $\pm \mathrm{SD} ; n=3)$
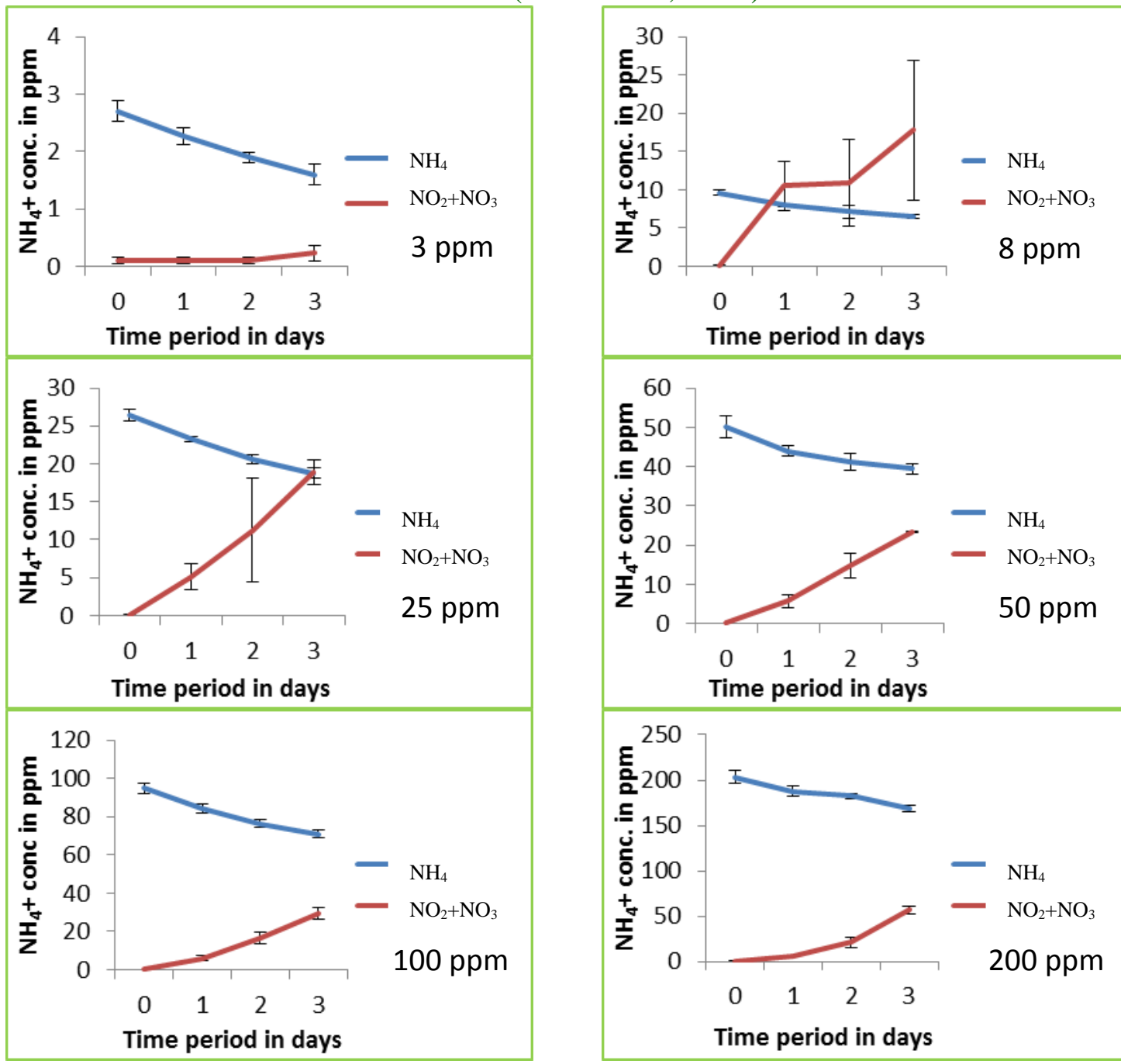
Fig.4 Influence of $\mathrm{NH}_{4}{ }^{+}$concentrations (3 ppm to $200 \mathrm{ppm}$ ) on amoA gene copy number of AOB-12 as determined by qPCR

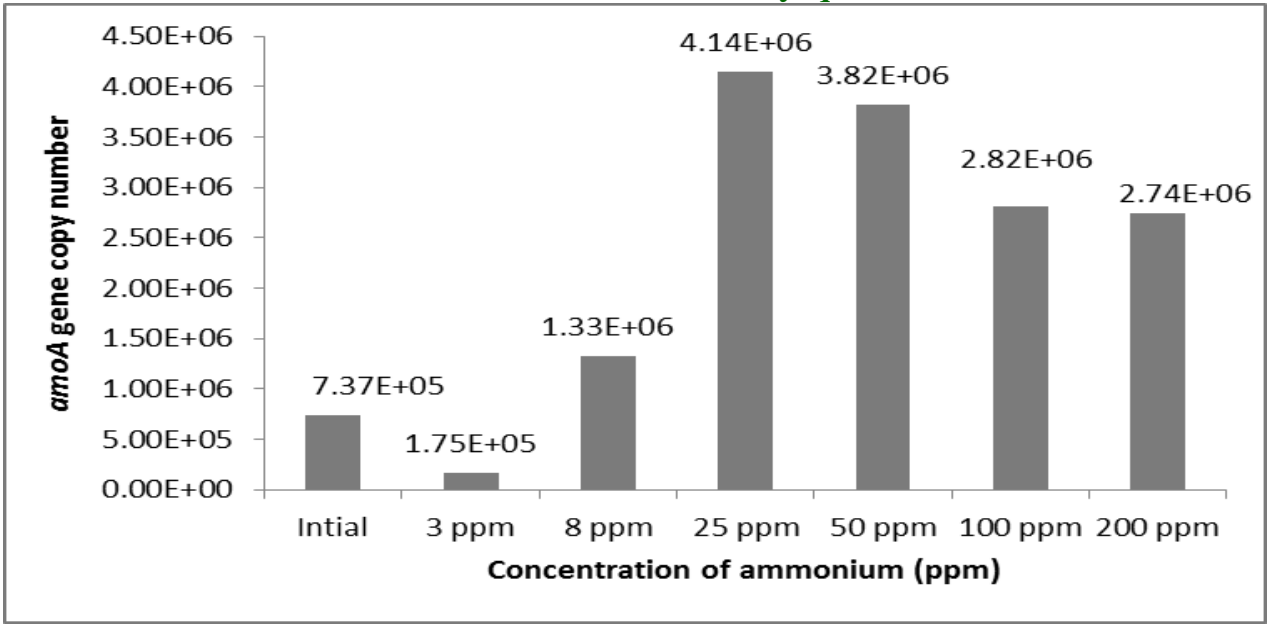

Fig.5 Influence of $\mathrm{NH}_{4}{ }^{+}$concentrations (3 ppm to $200 \mathrm{ppm}$ ) on ammonia removal efficiency of AOB-21 (mean $\pm \mathrm{SD} ; n=3)$

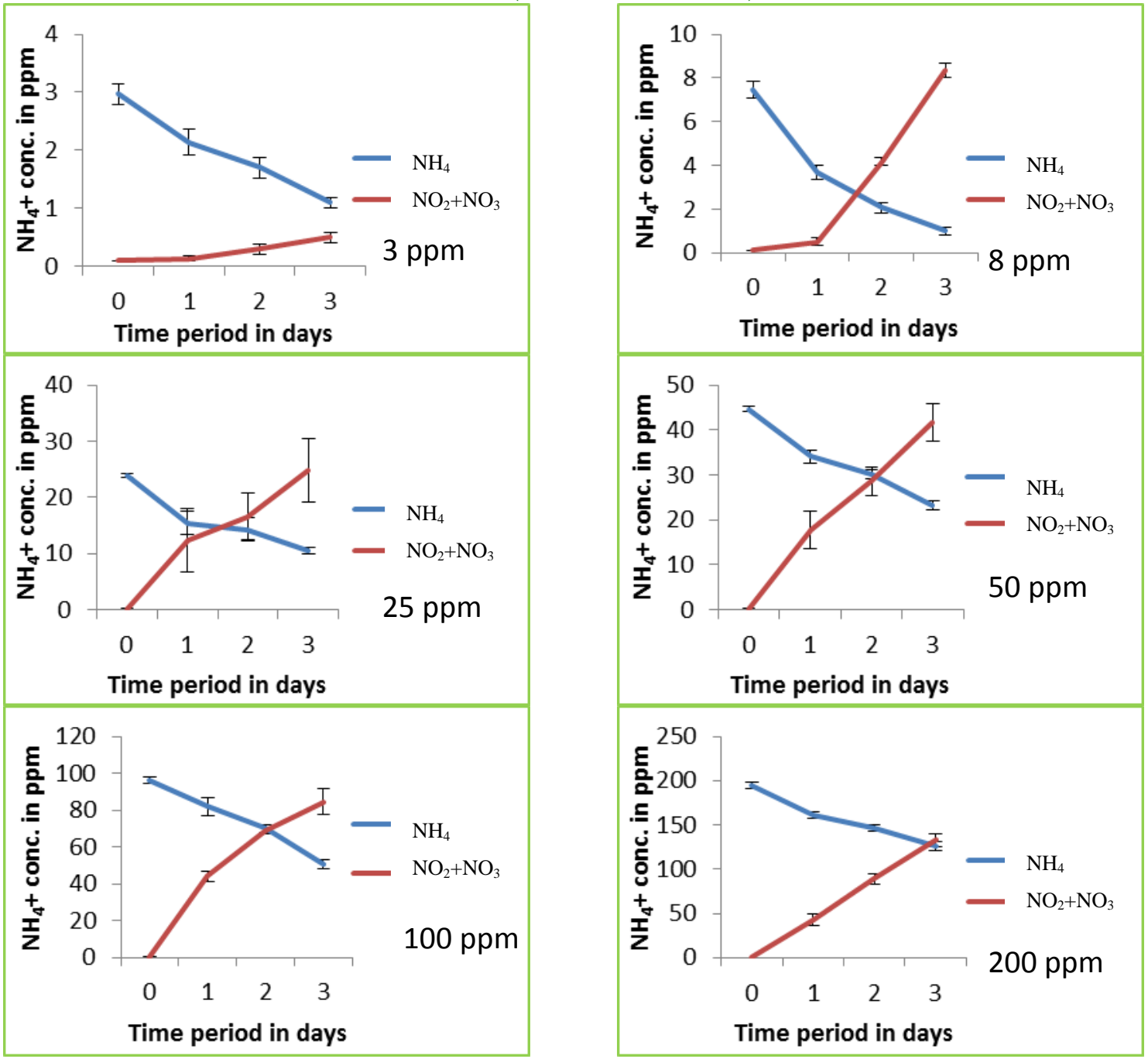


Fig.6 Influence of $\mathrm{NH}_{4}{ }^{+}$concentrations from 3 ppm to $200 \mathrm{ppm}$ on the amoA gene Copy number of AOB-21 as determined by qPCR

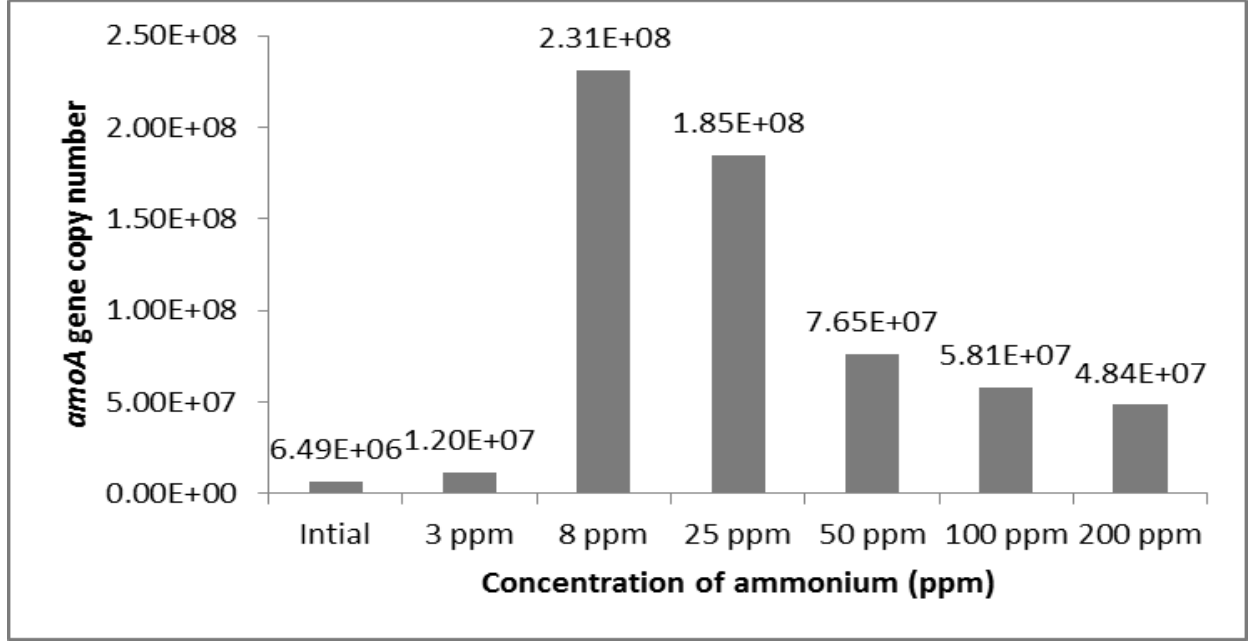

Fig.7 Influence of $\mathrm{NH}_{4}{ }^{+}$concentrations (3 ppm to $200 \mathrm{ppm}$ ) on ammonia removal efficiency of $\mathrm{AOB}$ consortium (AOB-12+AOB-21 isolate) (mean $\pm \mathrm{SD} ; n=3$ )
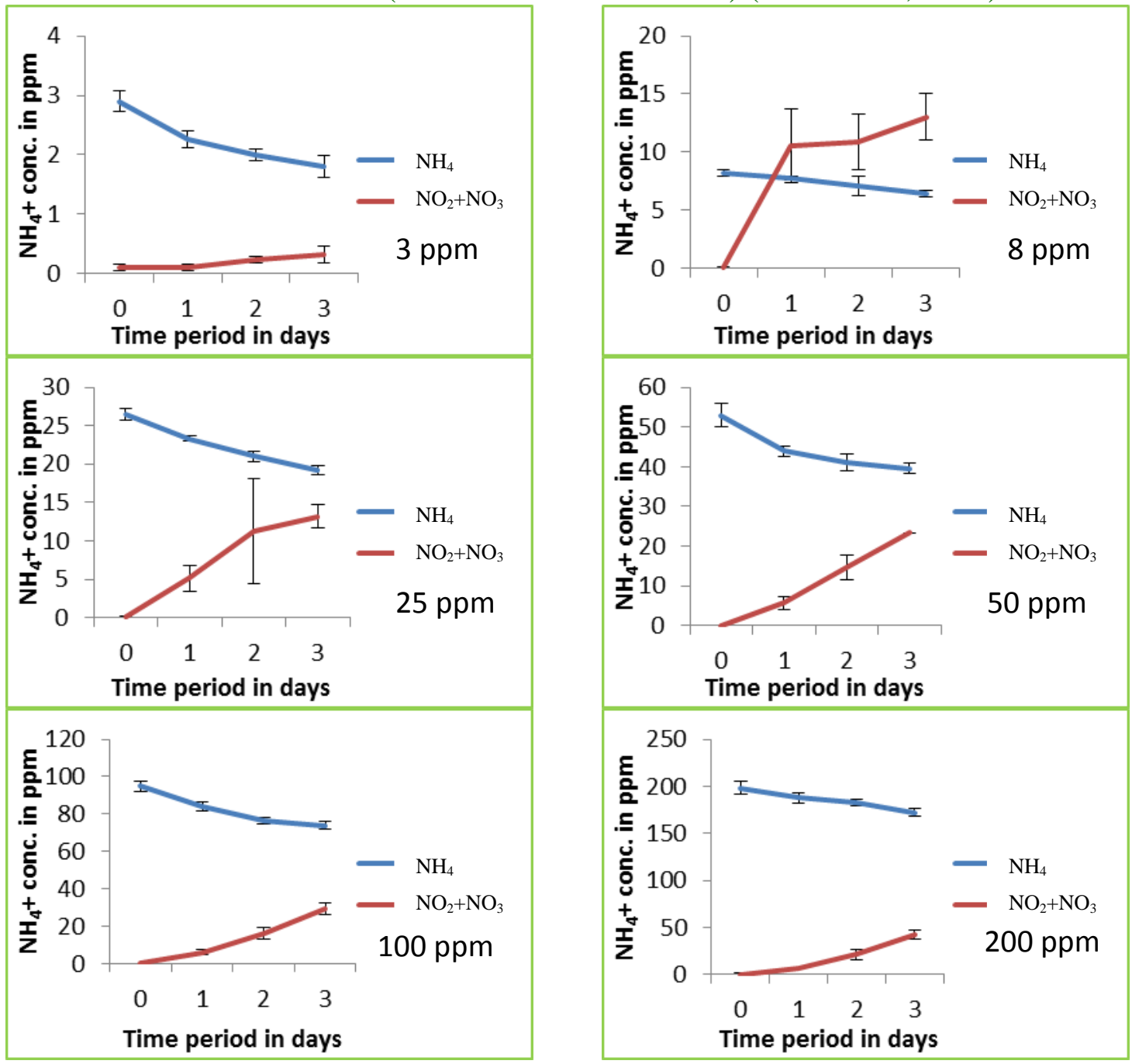
Fig.8 Influence of $\mathrm{NH}_{4}{ }^{+}$concentrations from 3 ppm to $200 \mathrm{ppm}$ on the amoA gene Copy number of AOB consortium (AOB-12+AOB-21) as determined by qPCR

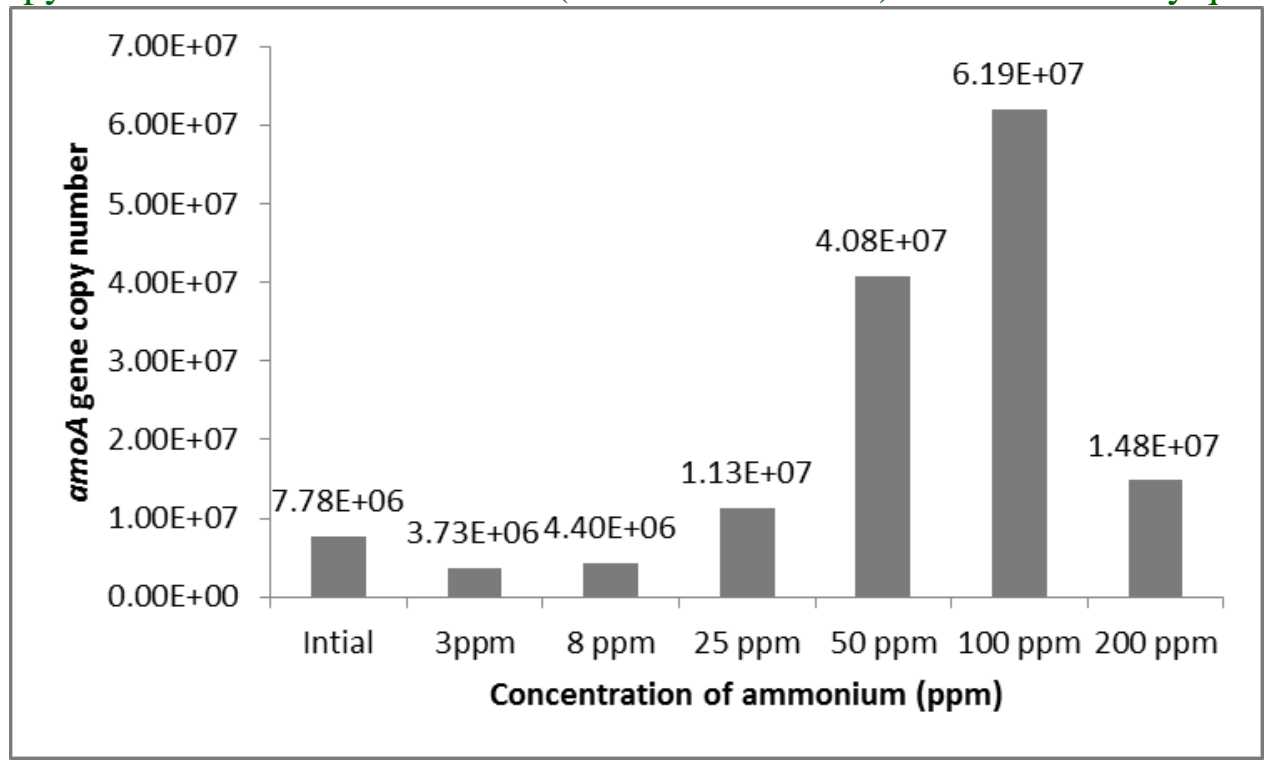

Real time q-PCR was done for the absolute copy number of amoA gene of $\mathrm{AOB}$ and is shown in figure 8 . The initial inoculum was added into the treatment samples having the average $a m o A$ gene copies was $7.78 \times 10^{6}$ and the maximum amoA gene copy numbers was found in $100 \mathrm{ppm}\left(6.19 \times 10^{7}\right)$, followed by 50 ppm $\left(4.08 \times 10^{7}\right), 200$ ppm $\left(1.49 \times 10^{7}\right)$, and $25 \mathrm{ppm}\left(1.33 \times 10^{7}\right)$ respectively.

The amoA gene copy number is comparatively less detected than the initial inoculum in $8 \mathrm{ppm}\left(4.399 \times 10^{6}\right)$ and $3 \mathrm{ppm}$ $\left(3.733 \times 10^{6}\right)$ concentrations. This consortium was found to be very useful in treating processing effluents. Since its ability to withstand all the expected conditions and it can remove the ammonia at all stages of ammonia concentration effectively.

The central theme of this study was to determine the effect of ammonium concentrations on nitrification rate of $\mathrm{AOB}$ isolates as well as $N$. europaea. Further, to study the amoA gene copy number of ammonia oxidizing bacteria upon exposure to different ammonium concentrations. Since, the ammonium concentrations in fish processing effluent treatment plants (FPETPs) are ranging from 2 to $200 \mathrm{ppm}$.

Our results are in agreement with the other studies, wherein members of the $N$. oligotropha cluster are less tolerant to high concentration of $\mathrm{NH}_{4}{ }^{+}$, while members of the $N$. europaea and $N$. eutropha clusters are primarily found in environments with high $\mathrm{NH}_{4}{ }^{+}$concentrations (Koops and Pommerening-Roeser, 2001; Bollmann et al., 2002; Koops et al., 2007; French et al., 2012). All the isolates in this study did not grow well at low ammonium concentration.

Low ammonium concentration in the media might have inhibited their growths and consequently the performances, Similar to results were also reported by earlier workers (Stehr et al., 1995; Suwa et al., 1997; Magalhaes et al., 2005). Since the members of AOB communities are significantly different from one another (Bernhard et al., 2005), it is also possible that some AOBs were more sensitive to low ammonium concentration as observed by Hopkinson et al.,(1999). Nevertheless ammonium concentrations used in this study were similar 
to in situ ammonium concentrations in fish processing effluent treatment plants (FPETPs).

In this study, all the isolates show more $a m o A$ gene copy numbers in $50 \mathrm{ppm}$ or $100 \mathrm{ppm}$ compared to those at lower ammonium concentration. This may be because of the favorable ammonium concentrations available in the media to perform the ammonia oxidising activity. From the experiments of French et al., (2012), it is observed that increasing ammonium concentration up to 18 ppm doubled the growth rate of the AOB cultures. However, the AMO activity was lost due to presence of high concentrations of nitrite in the medium resulting from ammonia oxidation activity (Stein and Arp, 1998). It was also clearly found that the more AMO activity was lost under alkaline conditions than acidic conditions.

It has been reported from the experiments with $N$. europaea, during the nitrification and denitrification process, around $7 \%$ of the total ammonium was transformed in to dinitrogen (Shrestha et al., 2002).

Stein and Arp (1998) found that the incubations with or without ammonium, resulted in the loss of ammonia oxidation activity after $24 \mathrm{~h}$. As the ammonium concentration increases to $270 \mathrm{ppm}$ and 900 ppm, the loss of ammonia oxidation activity was around $85 \%$ and $35 \%$ respectively. However, when grown without ammonium, there was no change observed in the ammonia oxidizing activity.

The native cultures obtained from fish processing effluents shows that these cultures are efficient in removal of ammonia at various ammonia concentrations and offer a promising biotechnological tool for treating the waste water from the effluents prior to release into the environment.

\section{Acknowledgements}

Authors gratefully acknowledge ICARNational Fund for Basic, Strategic and Frontier Application Research in Agriculture for the research grant and acknowledge the support of Prof. Daniel J. Arp, Oregon State University, USA in providing the $N$. europaea culture.

\section{References}

Adebisi, S.A., and Fayemiwo, K.A. (2011) Physiochemical properties of industrial effluents in Ibadan, Nigeria. Electr. $J$. Env. Agri. Fd. Chem., 10, 2026-2031.

Arp, D. J., Sayavedra-Soto, L. A., and Hommes, N. G. (2002) Molecular biology and biochemistry of ammonia oxidation by Nitrosomonas europaea. Arch. Microbiol., 178, 250-255.

Ausubel FM, Brent R, Kingsten RE, Moore DD, Seidman JG, Smith JA and Struhl K (eds) (1995) Short Protocols in Molecular Biology, 3rd edn. John Wiley and Sons, New York, NY.

Bellucci, M., and Curtis, T.P. (2011) Ammonia-oxidizing bacteria in wastewater. Methods Enzymol, 496, 269-286.

Bernhard, A. E., Donn, T., Giblin, A. E., and Stahl, D. A. (2005) Loss of diversity of ammonia-oxidizing bacteria correlates with increasing salinity in an estuary system. Environ. Microbiol, 7, 12891297.

Bollmann, A., Bär-Gilissen, M.J., and Laanbroek, H.J. (2002) Growth at low ammonium concentrations and starvation response as potential factors involved in niche differentiation among ammonia-oxidizing bacteria. Appl. Environ. Microbiol, 68, 4751-4757.

Ensign, S. A., Hyman, M.R., and Arp, D.J. (1993) In vitro activation of ammonia monooxygenase from Nitrosomonas 
europaea by copper. J. Bacteriol., 175, 1971-1980.

French, E., Kozlowski, J.A., Mukherjee, M., Bullerjahn, G., and Bollmann, A. (2012) Ecophysiological characterization of ammonia-oxidizing archaea and bacteria from freshwater. Appl. Envirorn. Microbiol, 78, 5773-5780.

Godornes, C., Leader, B.T., Molini, B.J., Centurion-Lara, A. and Lukehart, S.A. (2007). Quantitation of rabbit cytokinem RNA by real-time RT-PCR, Cytokine, 38: 1-7.

Hopkinson, C.S.J., Giblin, A.E., Tucker, J. and Garritt, R.H. (1999) benthic metabolism and nutrient cycling along an estuarine salinity gradient. Estuaries, 22, 863-881.

Koops, H.P, Purkhold, U., PommereningRöser, A., Timmermann, G. and Wagner, M. (2007) the lithoautotrophic ammonia-oxidizing bacteria, In: The prokaryotes, Dworkin, M., Falkow, S., Rosenberg, E., Schleifer, K-H. And Stackebrandt, E. (Eds), 5. Springer, New York, NY. p 778-811.

Koops, H.P. and Pommerening-Röser, A. (2001) Distribution and ecophysiology of the nitrifying bacteria emphasizing cultured species. FEMS Microbiol. Ecol., 37, 1-9.

Leininger, S., Urich, T., Schloter, M., Schwark, L., Qi, J., et al., (2006) Archaea predominate among ammoniaoxidizing prokaryotes in soils. Nature Lett., 442, 806-809.

Limpiyakorn, T., Sonthiphand, P., Rongsayamanont, C. and Polprasert, C. (2011) Abundance of amoA genes of ammonia-oxidizing archaea and bacteria in activated sludge of full-scale wastewater treatment plants. Biores. Technol., 102, 3694-3701.

Magalhaes, C.M., Joye, S.B., Moreira, R.M., Weibe, W.J., and Bordalo, A.A. (2005) Effect of salinity and inorganic nitrogen concentrations on nitrification and denitrification rates in intertidal sediments and rocky biofilms of the Douro River Estuary, Portugal. Water Res., 39, 1783-1794.

Martin-Laurent, F., Philippot, L., Hallet, S., Chaussod, R., Germon, J.C., et al., (2001) DNA extraction from soils: old bias for new microbial diversity analysis methods. Appl. Environ. Microbiol, 67, 2354-2359.

Reddy, A.D., Subrahmanyam, G., Girisha, S.K., Karunasagar, I., and Karunasagar, I. (2014). Detection of ammoniaoxidizing archaea in fish processing effluent treatment plants. Indian $J$ Microbiol, 54, 434-438.

Reddy, A.D., Subrahmanyam, G., Naveenkumar, S., Karunasagar, I. and Karunasagar, I. (2015) Isolation of ammonia-oxidizing bacteria from fish processing effluent treatment plants. Nat. Acad. Sci. Lett., 38(5):393-397.

Rotthauwe, J. H., Witzel, K. P., and Liesack, W. (1997) the ammonia mono oxygenase structural gene amoA as a functional marker: Molecular fine-scale analysis of natural ammonia-oxidizing populations. Appl. Environ. Microbiol, 63, 4704-4712.

Sambrook, J., Fritsch, E.F. and Maniatis, T. (1989) Bacterial media antibiotics and bacterial strains (A1). In: Molecular cloning: A Laboratory Manual, $2^{\text {nd }}$ ed. Cold Spring Harbor Laboratory Press, New York, p. A.1

Sankpal S.T. and Naikwade, P.V. (2012) Physiochemical analysis of effluent discharge of fish processing industries at ratnagiri India. Biosci. Dis., 3, 107111.

Shresthaa, N.K., Hadanob, S., Kamachia, T. and Okura, I. (2002) Dinitrogen production from ammonia by Nitrosomonas europaea. Appl. Catal. A: Gen., 237, 33-39. 
Stehr, G., Boettcher, B., Dittberner, P., Rath, G., and Koops, H. P. (1995) the ammonia oxidizing nitrifying population of the river Elbe estuary. FEMS Microbiol. Ecol., 17, 177-186.

Stein, L.Y. and Arp, D.J. 1998. Ammonium limitation results in the loss of ammonia- oxidizing activity in Nitrosomonas europaea. Appl. Environ. Microbiol, 64: 1514-1521.

Subrahmanyam, G., Hu, H. W., Zheng, Y. M., Archana, G., He, J. Z., and Liu, Y. R. (2014a). Response of ammonia oxidizing microbes to the stresses of arsenic and copper in two acidic alfisols. Applied Soil Ecology, 77, 5967.

Subrahmanyam, G., Shen, J. P., Liu, Y. R., Archana, G., and He, J. Z. (2014b). Response of ammonia-oxidizing archaea and bacteria to long-term industrial effluent-polluted soils, Gujarat, Western India. Environ. Monit. Assess, published online, DOI 10.1007/s10661-014-3678-9

Sulieman, A.M.E., Yousif, A.W.M., and Mustafa, A.M. (2010) Chemical, physicochemical and physical properties of wastewater from the sudanese fermentation industry (SFI). Fourteenth International Water Technology Conference, IWTC 14, Cairo, Egypt, 305-315.

Suwa, Y., Sumino, T., and Noto, K. (1997) Phylogenetic relationships of activated sludge isolates of ammonia oxidizers with different sensitivities to ammonium sulfate. $J$. Appl. Microbiol. 43, 373-379.

Wells, G., Park, H., Yeung, C., Eggleston, B., Francis, C. et al., (2009) Ammoniaoxidizing communities in a highly aerated full-scale activated sludge bioreactor: betaproteobacterial dynamics and low relative abundance of Crenarchaea. Environ. Microbiol, 11, $2310-2328$

\section{How to cite this article:}

Devivaraprasad Reddy, A., G. Subrahmanyam, M.M. Dechamma, B.B. Nayak, Iddya Karunasagar and Indrani Karunasagar. 2017. Effect of Ammonia Concentration on the Nitrification Potential of Ammonia Oxidizing Bacterial Isolates from Fish Processing Waste Effluents. Int.J.Curr.Microbiol.App.Sci. 6(7): 2155-2166. doi: https://doi.org/10.20546/ijcmas.2017.607.253 